\title{
Analysis of the Relationship Between New Stock Issue and Price Determination and Information Efficiency
}

\author{
Haoyuan Wang ${ }^{1}$, Wangui Sun ${ }^{1}$ \\ ${ }^{1}$ School of Economics \& Management Northwest University \\ qijkwhy@163.com
}

\section{ABSTRACT}

Based on the understanding of new shares, the price is determined and the relationship between the efficiency, according to the presented between the multi-level and multi-dimensional characteristics, build a has the internal logic relations, can be intuitive show the theoretical framework of influence factors, and using covariance structure model analysis method of experiment and analysis, It is clear that the information efficiency of IPO pricing in China is limited.

Keywords: IPO; The price, Sure, Information, Efficiency, Covariance structure model

\section{PRESENTATION}

Understand the current scientific research personnel to the three research analysis shows that most of the literature was optimized in different degrees of new shares an initial public offering (IPO) pricing information efficiency, and build the influence factor of different types of new pricing linear regression model, and then with the method of econometrics to in-depth discussion and research. Therefore, under the construction background of the new era, in order to better grasp the relationship between the three and understand the impact of information and market environment on stock prices, the covariance structure model is used to conduct in-depth discussion. ${ }^{[1-4]}$

IPO is one of the most common fund-raising methods in the capital market. The establishment of the new stock price is an important link in the stock issuing market, which involves the benefits of investors, underwriters and issuing enterprises, and affects the actual performance of the stock after listing. Whether the pricing is scientific or not determines the resource allocation efficiency of the stock market. The offering price of new shares will be affected by its contained value and market supply and demand. In essence, the information efficiency of IPO pricing directly shows all the information related to it. In other words, the efficiency of price response to information determines the pricing efficiency, which is also the ultimate efficiency of resource allocation. According to the analysis of practical cases, the response efficiency of price to information is mainly manifested in two aspects: information quantity on the one hand, and information structure on the other. According to the analysis of the research results of Srivea et al., in a relatively ideal state, the basic value information of a company is the main basis for determining the stock price, because its intrinsic value is the fundamental of stock pricing, while the issuing information and market environment information have less influence on it. Therefore, a reasonable release price should not only present relevant information, but also make clear one by one on the basis of knowing more information about intrinsic value.

\section{METHODS, DATA AND VARIABLES}

\section{1 methods}

This paper studies the selected covariance structure model, which is mainly used to analyze the relationship between observed variables and latent variables as well as their existence, which belongs to a diversified statistical method.

\section{2 data}

The data used in my research are mostly from CSMA database, and some of them are from the instructions and bulletin books provided by Shanghai Stock Exchange Website and Huatai Securities Website. At the same time, we also collected a lot of relevant information from the consulting network of Chinese listed companies. ${ }^{[5-8]}$ 


\section{3 variable}

Combined with Table 1 below, the path model as shown in Figure 1 is constructed and evaluated and considered from the perspective of the IPO price.
Among them, the internal value of the publishing company belongs to the internal latent variable, while the exogenous latent variable includes the publishing factor and the market environment.

Table 1 Variables and their criteria

\begin{tabular}{|c|c|c|c|}
\hline Latent variable type & Latent code & Look at the variable code & Measurement standard \\
\hline \multirow[t]{7}{*}{ Endogenous variable } & $\begin{array}{l}\text { Value of New Shares Issued } \\
\text { (A) }\end{array}$ & Price of new shares issued (E) & $\begin{array}{l}\text { The price of the initial } \\
\text { offering }\end{array}$ \\
\hline & \multirow[t]{6}{*}{ Intrinsic value factor (B) } & Income on net assets $(\mathrm{F})$ & $\begin{array}{l}1 \text { year prior to issuance by the } \\
\text { issuing company }\end{array}$ \\
\hline & & Earnings per Share $(\mathrm{G})$ & $\begin{array}{l}1 \text { year prior to issuance by the } \\
\text { issuing company }\end{array}$ \\
\hline & & Total Assets $(\mathrm{H})$ & $\begin{array}{l}1 \text { year prior to issuance by the } \\
\text { issuing company }\end{array}$ \\
\hline & & $\begin{array}{l}\text { Growth rate of main business } \\
\text { revenue (I) }\end{array}$ & $\begin{array}{l}3 \text { years prior to issuance by } \\
\text { the issuing company }\end{array}$ \\
\hline & & Flow ratio $(\mathrm{j})$ & $\begin{array}{l}1 \text { year prior to issuance by the } \\
\text { issuing company }\end{array}$ \\
\hline & & $\begin{array}{l}\text { Growth rate of main business } \\
\text { revenue }(\mathrm{K})\end{array}$ & $\begin{array}{l}3 \text { years prior to issuance by } \\
\text { the issuing company }\end{array}$ \\
\hline \multirow[t]{10}{*}{ Exogenous variables } & \multirow[t]{4}{*}{ Release factor (C) } & Circulation (L) & $\begin{array}{l}\text { According to the published } \\
\text { circulation }\end{array}$ \\
\hline & & Distribution Method (M) & $\begin{array}{l}\text { The online distribution under } \\
\text { the application approval } \\
\text { system is } 1\end{array}$ \\
\hline & & $\begin{array}{l}\text { Lead Underwriter Reputation } \\
(\mathrm{N})\end{array}$ & $\begin{array}{l}\text { Domestic well-known } \\
\text { investment bank underwriting } \\
\text { is 1 }\end{array}$ \\
\hline & & $\begin{array}{l}\text { Lead Underwriter Registered } \\
\text { Capital (O) }\end{array}$ & $\begin{array}{l}\text { According to the registered } \\
\text { capital published }\end{array}$ \\
\hline & \multirow[t]{6}{*}{$\begin{array}{l}\text { Market environment factors } \\
\text { (D) }\end{array}$} & Publish tutoring and (P) & $\begin{array}{l}\text { The sum of the two months } \\
\text { before release }\end{array}$ \\
\hline & & Market Index (R) & $\begin{array}{l}\text { A Shanghai stock index before } \\
\text { the issue }\end{array}$ \\
\hline & & Successful rate (S) & $\begin{array}{l}\text { Circulation divided by valid } \\
\text { subscriptions }\end{array}$ \\
\hline & & Industry Characteristics (T) & $\begin{array}{l}\text { The traditional industry of } \\
\text { distribution company is } 1\end{array}$ \\
\hline & & Registration Area (U) & $\begin{array}{l}\text { The publishing company is in } \\
\text { the eastern region with } 1\end{array}$ \\
\hline & & First-day turnover rate (V) & $\begin{array}{l}\text { Number of shares traded } \\
\text { divided by outstanding share } \\
\text { capital }\end{array}$ \\
\hline
\end{tabular}

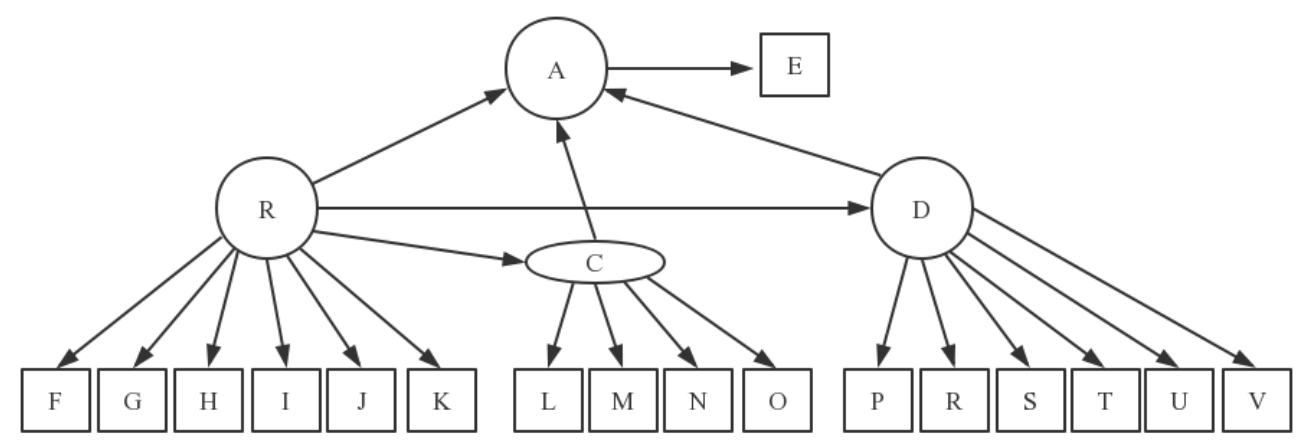

Fig1. The relationship path model of factors influencing the IPO price 


\section{RESULT ANALYSIS}

In this study, AMOS4.0 statistical analysis software was selected, and the following indicators were used to evaluate the final fitting effect: First, chi-square test. If the ratio between chi-square and degree of freedom is lower than 3 , then the overall fitting effect is proved to be superior. Second, the goodness of fit index. This value must be controlled between 0 and 1 , and is generally assumed to be more than 0.9 , which proves that the observed data fully represent the defined model. Third, approximate the mean square of error. According to the analysis results of previous experimental models, this value should be lower than 0.8 . Only in this way can we ensure that the data obtained and the model defined are relatively fit. Fourth, the normalizing fitting index. The index should exceed 0.95 , and as long as the index exceeds 0.9 , it represents a high model fitting degree. Fifthly, Bentler comparative fitting index. Generally speaking, it will be controlled between 0 and 1 , and more than 0.9 represents a strong model fitting degree.

Table 2 below shows the fitting values obtained in this research on covariance structure model. Combined with this content, it can be seen from a comprehensive discussion that all relevant values were tested at a high significance level and achieved a high fitting effect, which indicates that the research model in this paper has a strong explanatory ability. At the same time, according to the standardized path coefficient calculation and analysis of the impact of various latent variables on the IPO pricing, it can be gradually found that the total assets, liquidity ratio and issuance and other factors do not have a great impact on it, which proves that the IPO price is limited when reflecting the issuing related factors and information.

Table 2 Main fitting values in the model

\begin{tabular}{|l|l|l|l|l|l|l|}
\hline cmindf & gfi & rmsea & tli & cfi & $\mathrm{x}^{2}$ & $\Delta \mathrm{x}^{2}$ \\
\hline 1.987 & 0.849 & 0.431 & 0.954 & 0.26853 & 133.71 & $128.02^{* * *}$ \\
\hline 2.850 & 0.921 & 0.568 & 0.923 & 0.931 & 131.73 & $106.54^{*}$ \\
\hline 2.824 & 0.918 & 0.059 & 0.916 & 0.926 & 73.85 & $67.31^{* *}$ \\
\hline 1.629 & 0.903 & 0.265 & 0.902 & 0.927 & 242.19 & $239.81^{*}$ \\
\hline 2.654 & 0.781 & 0.937 & 0.920 & 0.916 & 184.52 & $162.56^{* * *}$ \\
\hline 2.903 & 0.498 & 0.646 & 0.874 & 0.905 & 383.25 & $378.35^{*}$ \\
\hline 3.021 & 0.942 & 0.085 & 0.893 & 0.802 & 341.48 & $328.77^{*}$ \\
\hline
\end{tabular}

In essence, the ipo pricing is a complex and changeful systems engineering, when considering price, not only to analyze the intrinsic value, it contains more institute for environment and distribution factors, and pay attention to balance the rights and interests of enterprises or institutions concerned effect, to put forward a more systematic and reasonable price of new shares. According to the analysis of the above research results, the stock issuance system in China has been continuously innovating in the social and economic development, and has improved the pricing efficiency in a certain sense, which proves that the stock issuance pricing in China is reasonable, and there is information efficiency. Especially in the future urban construction and development, with the innovative application of big data technology, the IPO pricing must be under the control of relevant systems and constantly improve the information content of the pricing, so as to optimize the information structure and improve the final pricing efficiency at the same time.

\section{CONCLUSION}

To sum up, from the perspective of experimental analysis, in order to further improve the information efficiency of IPO pricing, it is necessary to strictly control the operating environment of China's stock market. On the one hand, on the basis of building an open and efficient information exchange mechanism, the proportion of tradable shares in the market should be increased. On the other hand, on the basis of optimizing delisting mechanism, investors should be guided to construct the correct concept of value investment in risk control. In addition, strengthen the training and application of professionals, pay attention to the market innovation system, optimization and prevention, only in this way can we further optimize the information efficiency of China's IPO pricing, but also can guide China's social economy towards the sustainable development of the goal of steady progress.

\section{REFERENCES}

[1] Nakhipbekova S , Baibosynova G , $\mathrm{N}$ Batyrova, et al. Analysis of the Relationship between Energy Price Changes and Stock Market Indices in Developed Countries[J]. International Journal of Energy Economics and Policy, 2020, 10.

[2] Kang S B , Lee S H . The Relationship between Capital Market Information Efficiency and Stock Price Volatility in Korea. 2020.

[3] Almeida-Santana A , David-Negre $\mathrm{T}$, Moreno-Gil S . New digital tourism ecosystem: understanding the relationship between information sources and sharing economy platforms $[\mathrm{J}]$. International Journal of Tourism Cities, 2020, 6(1):1-7.

[4] Topuz S G , Dademir Z . Analysis of the relationship between trade openness, structural change, and income inequality under Kuznets curve hypothesis: The case of Turkey[J]. The 
Journal of International Trade \& Economic Development, 2020, 29.

[5] Baygn A . Analysis of the Relationship between Real Effective Exchange Rate, Common Equity Tier 1 Ratio and Return on Equity: Evidence from Turkey[J]. Alphanumeric Journal, 2019, 7.

[6] Alexakis C, Pappas V, Skarmeas E . Market abuse under different close price determination mechanisms: A European case $[\mathrm{J}]$. International Review of Financial Analysis, 2021(4):101707.

[7] Wei J . Analysis on the Collection and Risk Control of the Basis of Property Price Determination. Price:Theory \& Practice, 2019.

[8] Price transmission after the determination of rice ceiling price in South Sumatra Province: analysis of secondary and empirical data[J]. IOP Conference Series Earth and Environmental Science, 2020, 497:012042. 